\title{
CARnivorous Plants of Australia's TOP END
}

BoAZ NG • Melbourne •Victoria • Australia・ng.boaz@gmail.com

Keywords: Top End, Northern Territory, Australia, Utricularia, Drosera, Byblis.

Abstract: The Top End of the Northern Territory in Australia is a centre of diversity for carnivorous plants. In May 2021, Boaz Ng embarked on a 10-day expedition to document these plants in the wild and photographed over 45 taxa across 3 genera. This field report recounts his experience and focuses on a selection of species that represent adaptations towards the wet and dry seasonal dichotomy of the region.

Acknowledgement of Country: The author would like to acknowledge the Traditional Owners of the land on which this expedition took place, including the Larrakia, Werat, Koongurrukun, Wajray, Marranunggu, Marrathiel, Wulna, Limilngan, Ngomburr, Gun-djeihmi, Warramal, Gaagudju, Bukurnidja, Konbudj, Mbukarla, Amarak, Wagiman, Mangarrayi, Yangman and Jawoyn Peoples, among others. Their continued custodianship of the land and protection of its biodiversity is especially relevant to this article.

A blast of heat hit my face as if the doors of a furnace were opened. Instantly, beads of sweat materialized and made me wonder how I was going to possibly make it through 10 entire days of botanizing in the oppressive tropical climate. After a restless night spent dreaming about the carnivorous plants of the Top End, an agitated sensation comprising half excitement and half delirium began to fill the car, quickly building thicker than the humidity in the air.

The "Top End", an Australianism for the tropical regions of the Northern Territory, is known for its two strikingly dichotomous seasons - the "wet" with daily monsoonal downpours and the "dry" in which not a single drop of rain falls. This is an oversimplification, with the Indigenous peoples of the region recognizing up to six distinct seasons. Our expedition was timed for the start of Yekke after the floodwaters recede, gambling that the La Niña conditions would prolong the wetness and that we would catch the narrow period when the greatest number of carnivorous plants can be seen.

My eyes glanced nervously for signs of water as we arrived at the Howard Sand Plains, a habitat formed by a thick deposit of sand in the floodplain the Howard River east of Darwin. With the onset of the monsoon, the river swells and inundates the sand sheets. When the rains cease, the water rapidly drains to sea and exposes the substrate to air once again. It is during this brief transitional period between the wet and dry that the bladderworts, of which there are at least 26 species in the sand plains alone, come to bloom. In the trail, deeply eroded ravines hinted of the now vanished floodwaters and I anxiously approached the steadily browning grasses flanking the track, hoping that I hadn't arrived too late.

Suddenly I found myself surrounded in a beautiful field of Utricularia leptoplectra, with hundreds of purple lobed flowers swaying gently in the breeze. Glistening specimens of Drosera aquatica (Fig. 1) glowed like jewels amongst the damp shadows as they caught the morning sun with their spidery arms. As its name suggests, the species is adapted to float in floodwaters and is even known to complete its life cycle without ever touching the ground. The water table was still high enough to flow just under the sandy surface and seeped out to form shallow channels wherever old trails had

\footnotetext{
${ }^{1}$ A season of the Kakadu region in the Kunwunjku and Kundjeyhmi languages (among others). Each language group has their own names and interpretations of the various seasons.
} 


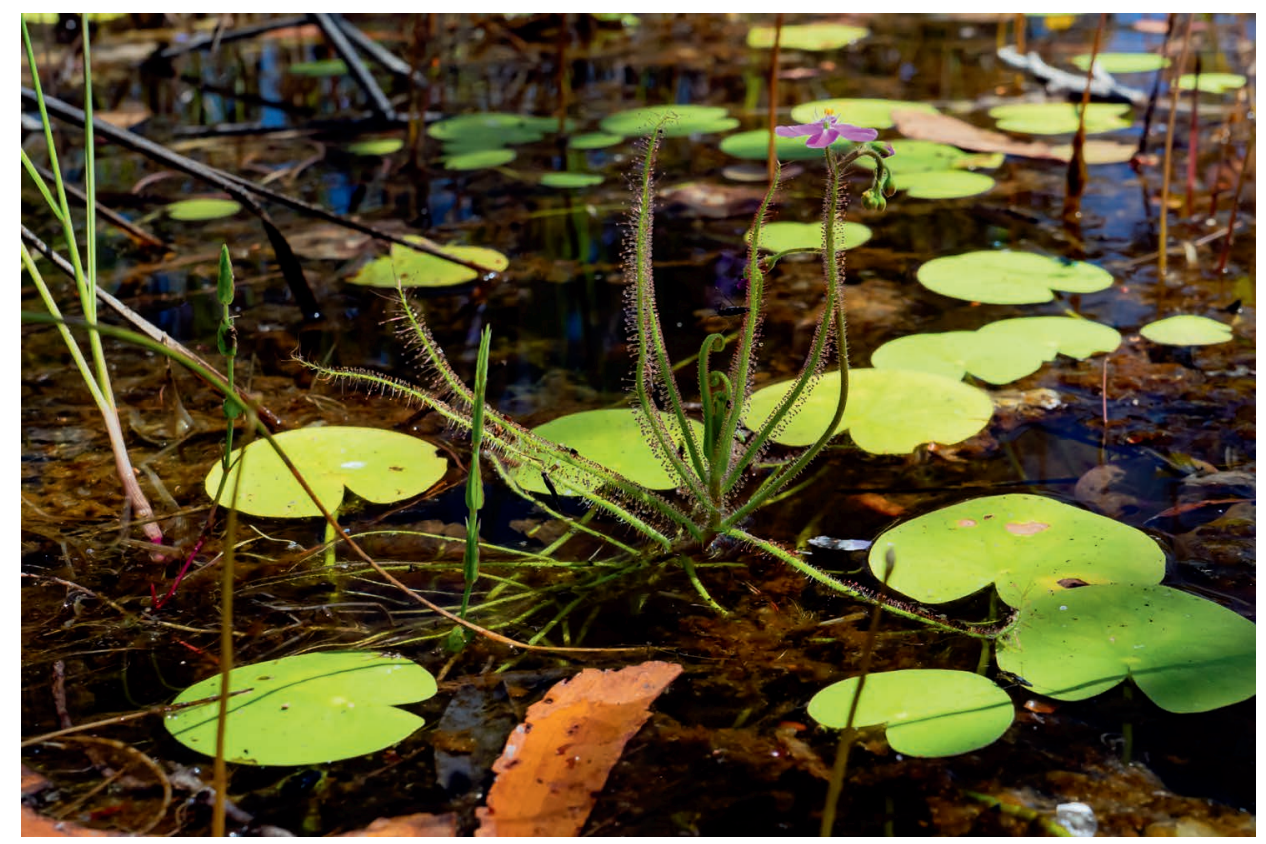

Figure 1: Drosera aquatica.

been dug. At their edges grew U. circumvoluta, with a twining peduncle that spirals around sedges for support, and inside the pools I even found $U$. adamsii, a recently described floating species that occupies shallow wetlands. I was amazed at the diversity in both plants and environmental niches, having spotted 15 species in a trail just 500 meters in length.

The following day, we embarked on our road trip around the Top End and drove out of the city towards Berry Springs. Along the way, I had identified several sites where I hoped to find the iconic D. falconeri (Fig. 2; Front Cover). Renowned for its disc-like laminae that are reminiscent of the Venus flytrap, the species has captured the imaginations of enthusiasts worldwide and no pilgrimage to the Territory would be complete without sighting the plant.

I soon discovered out that finding it was going to be more challenging than I thought. The species is mainly known from the floodplains of major rivers south west of Darwin, occupying sandysilt alluvial deposits that lie beneath grasses so thick and tall that you can barely see through them. Luckily by this time, they were almost desiccated and snapped without resistance. I tried my best to ignore the irritation from the increasing number of sharp seeds lodged in my socks as I traced the banks of the dried three-meter-deep ravine. Noticing that the soil was silty and grey, I kicked down some grasses to expose what I had come to find.

Like other members of the section Lasiocephala, D. falconeri is well adapted for the climatic dichotomy of the region. With the onset of the dry season, it retreats underground as a resting corm, using the now rock-hard substrate as insulation against heat. This habit means that the species is amongst the first in the complex to enter dormancy, dropping its leaves as soon as the rains stop. Unfortunately, the plants were already well past their dewy prime by the time I had arrived. Whilst an observation of dormant plants contributes valuable field knowledge, I was admittedly disappointed, and I trudged back to the car rather scratched up from the grasses I had to push through. 


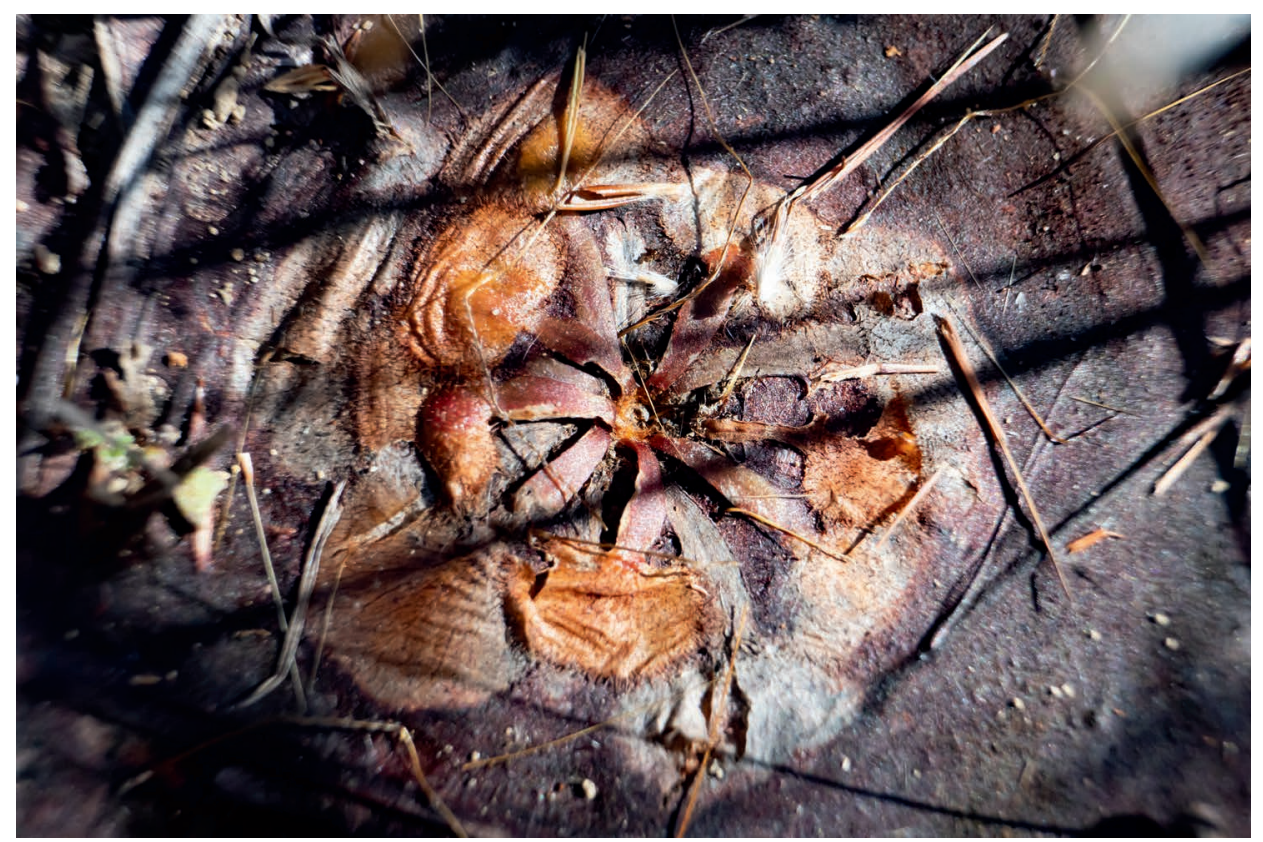

Figure 2: Drosera falconeri.

We awoke before sunrise in preparation for a massive day in the Litchfield National Park. The region is known for its gigantic waterfalls that plunge off cliffs into the plains below and it was in the watercourses of the sandstone escarpment that we focused our search. Timing the exploration of these creeks is always risky - arrive too early and they're still raging torrents too forceful for plants; too late and they've already dried out, the waters from the elevated plateau disappearing especially fast.

The major stop for the day was a wide-banked cascade flowing off the escarpment that I was hopeful would provide just the right balance in size to support carnivorous plants. I soon found out that getting there would be no easy feat. The oppressive humidity and searing heat in the exposed plateau turned what would otherwise be a gently undulating stroll into a horrible slog. After what seemed like hours of almost collapsing from heat stroke, the caressing sound of flowing water gave me a burst of energy required to make the final stretch. Plunging into a rock pool fully clothed, I was instantly rejuvenated with the sight of $D$. burmannii at the water's edge.

In the fast-flowing waters, I saw the leaves of $U$. fulva growing directly in the current. However only a few scattered blooms were present - far from the large flowering events I was hoping to photograph. Further downstream, amazing specimens of Byblis liniflora (Fig. 3) grew directly in the rock face. Just a month or two ago, the site would have been covered by the stream and in a few weeks, the waters will stop supplying the fractures the plants occupy. For this species, seed is an important mechanism for surviving both the wet and dry seasons, wedging themselves tightly within the tiniest cracks until the water level is just right to spring forth a new generation of plants.

After the Litchfield National Park, we circuited back to greater Darwin where we spent the day surveying a few dams and lagoons. Unlike the ephemeral sand plain wetlands, these permanent 


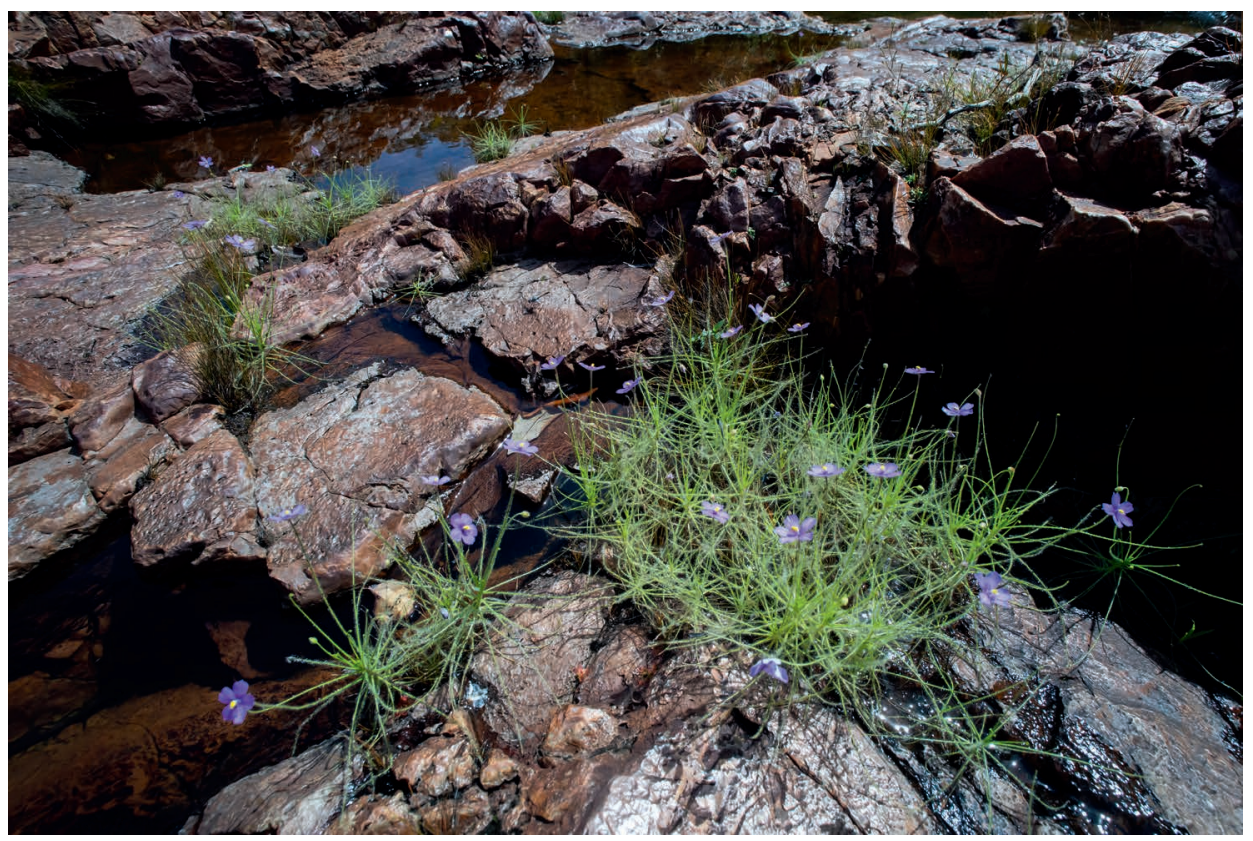

Figure 3: Byblis liniflora.

bodies of water can support obligate aquatic plants such as the suspended aquatic bladderworts. The deep-water habitats are also home to the deadly saltwater crocodile...

We arrived at a lagoon in the outer suburbs to have lunch. At the picnic area, a dilapidated handmade sign warned of crocodiles, which are known to sometimes slip through the caged traps set to relocate them. My heart began to race as I spied the water's edge, nervously keeping one eye out for crocs. I was enticed by gigantic strands of $U$. muelleri (Fig. 4) floating in the clear waters, each stem reaching over a meter long with hundreds of bladder traps arranged on bushy whorls of leaves. With a shot of adrenaline, I approached the water for just a few seconds to take images before retreating to the safety of higher ground.

While a permanently wet habitat provides a stress-free lifestyle for the suspended aquatic bladderworts, it also presents a problem when the plants are trying to reproduce sexually. Whereas the terrestrial bladderworts can simply produce a flower stem anchored off the ground, the floating species must somehow elevate their blooms above the surface of the water and keep them stable enough for insects to land on them. Utricularia muelleri has evolved an elegant solution and sends up a long stem with a star-like structure at the end. When this structure reaches the surface, it inflates into a gas-filled float, out of which emerges the inflorescence. This float ensures that the blooms are held stably above the surface of the water, allowing for efficient pollination.

By now we were nearly halfway through our journey, with the next three days to be spent in the iconic Kakadu National Park. Situated at the western edge of the Arnhem Plateau, the region is characterized by its dramatic cliffs, vast wetlands and ancient cultural heritage. As we drove into the area, we noticed smoke emanating from the highway and even saw flames lapping by the roads edge!

The wet season produces an enormous number of tall grasses that completely carpet the landscape. When the rain stops, the grasses dehydrate into thickets of extremely flammable tinder. Wide- 


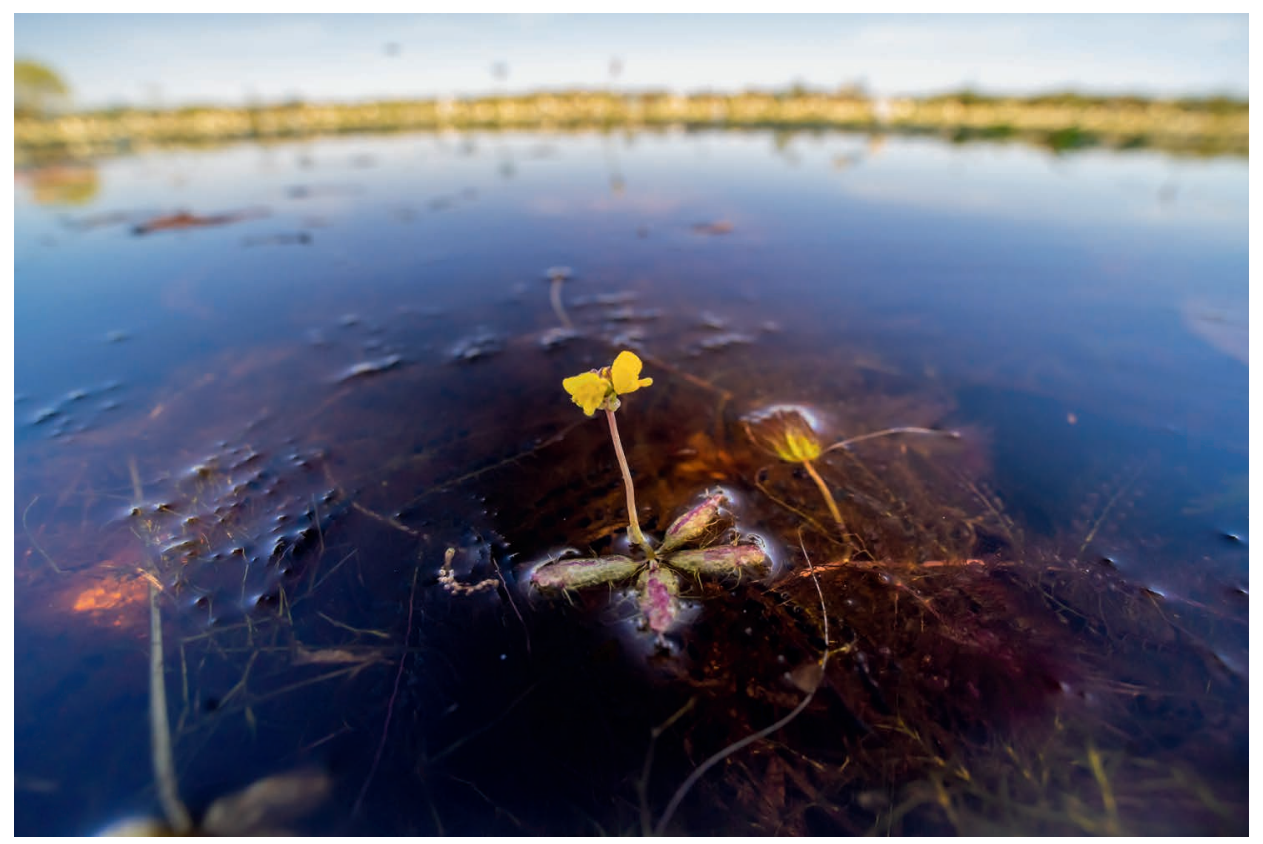

Figure 4: Utricularia muelleri.

spread fires grip the countryside during the dry season, so low-intensity controlled burns are utilized to create strategic firebreaks and rejuvenate the land. To me, the fires enhanced the spirituality of the sacred landscape. Seeing the Burrungkuy outcrop, an ancient meeting place with rock art dating back more than 20,000 years, glow an incandescent red as the evening sun filtered through the smoke was surely one of the most reflective experiences of my life. I was also left to wonder how the sundews growing in the area would cope with the fires.

As we left Kakadu, I inspected a section of forest that was burned just a few days before. Scattered in the undergrowth were rosettes of D. dilatatopetiolaris (Fig. 5), which had begun to enter its dormant phase by reducing the size of their leaves and increasing the amount of trichomes produced on their stems. This results in a densely packed bud of white hairs, which gives the complex the common name of the "woolly sundews". In patches which were burnt, I noticed the singed remains of old rosettes, but the hairy resting bud seemed to be able resist the flames. I find it amazing that these tough plants had to not only survive the annual drought, but also the fire ubiquitous in their habitat.

Our journey continued south towards Katherine, which is known for its majestic gorges and plunging waterfalls that fill the landscape of the Nitmiluk National Park. This region is placed at the transition zone between the wet tropics and arid interior of the Territory. Being situated inland, the area was well and truly in the grips of the dry season and I was worried that I had arrived too late.

We started the hike up the escarpment early in the day and was surprised by the decidedly bitter morning air. I was on the lookout out for small ephemeral streamlets and wet skeletal soils over the sandstone bedrock, a niche that is almost always associated with carnivorous plants in Australia. While the stained rocks and eroded patterns hinted of their presence, they had long been desiccated by the heat that was really beginning to build up. The main river itself was too large and forceful to support populations of bladderworts so I turned my attention towards a dry creek bed and followed it upstream. 


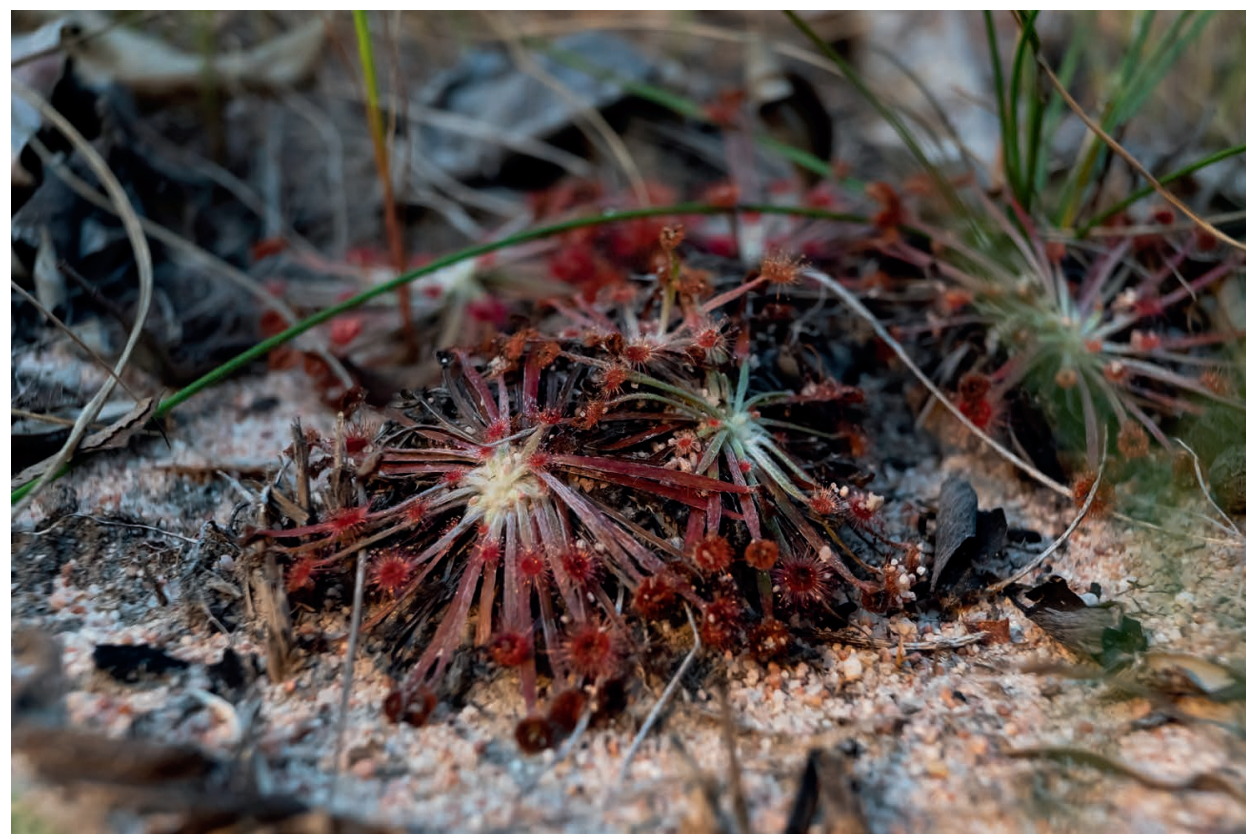

Figure 5: Drosera dilatatopetiolaris.

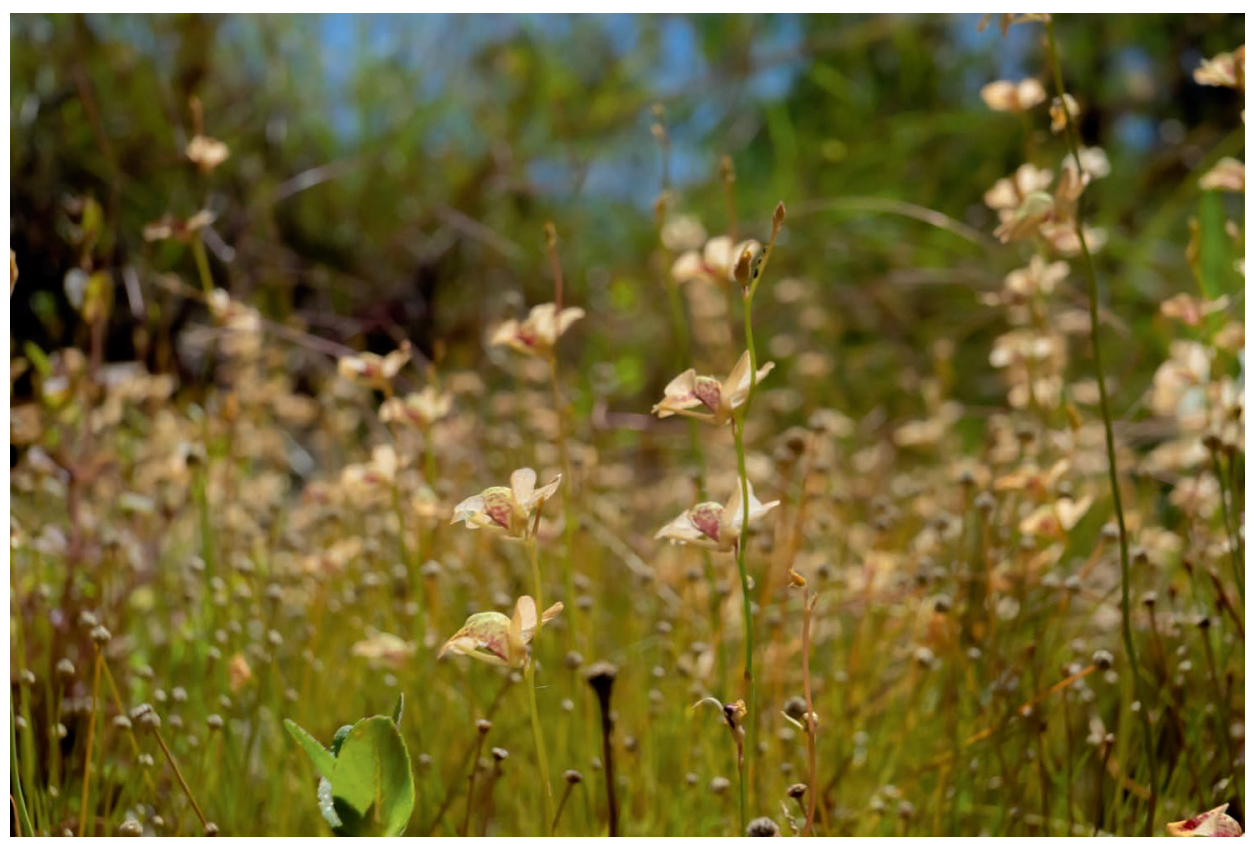

Figure 6: Utricularia fulva. 
As I followed the creek, the substrate started to moisten and soon a trickle of water started flowing. I was relieved to find that the sides of the rivulets were painted orange from the myriads of $U$. fulva (Fig. 6) that were blooming en masse. The species is notable for its attractive tawny and brickred petals, which are colored just like the sandstone on which it grows. In contrast to the flowerless leaves I had seen in the Litchfield, which were submerged under a fast-flowing stream, the plants here were now located on the steadily receding sandbanks. The late blooming period allows the species to recolonize the site from seed, rather than having it washed away by the raging torrent present at the height of the wet season.

On the final day of the journey, I returned to the Howard Sand Plains for a full day of exploration. The water table had dropped significantly in just 10 days, and the sites I had explored before were visibly drier. The floating stems of $U$. adamsii had perished and were replaced by the flowers of $U$. gibba, a species that is induced to bloom when its aquatic stolons are stranded in drying mud. There was still one particularly rare species that I wanted to find. With the relentless sun directly above me, I trekked along an old trail deep into the bush, blindly hoping that the site would somehow still be wet enough. After an hour, I came across some rather gothic looking magnetic termite mounds, a biological beacon signalling that I had arrived at the right place in the floodplain.

Delighted that the ground was soaked, I dropped my backpack and scoured the area for the elusive plant. The five-lobed $U$. holtzei, pin-sized $U$. quinquedentata, and showy $U$. odorata were everywhere but these weren't the bladderwort that I was trying to find. After an hour spent searching a plot of around twenty square meters, the oppressive climate overcame me. As I bent over to pick up my bag, I saw an alien bloom with two long devil-like prongs and a gaping beak staring straight at me! Despite its somewhat generic habitat, U. dunstaniae (Fig. 7) is notoriously difficult to observe, perhaps due to a very specific niche or narrow flowering period. The water level in the

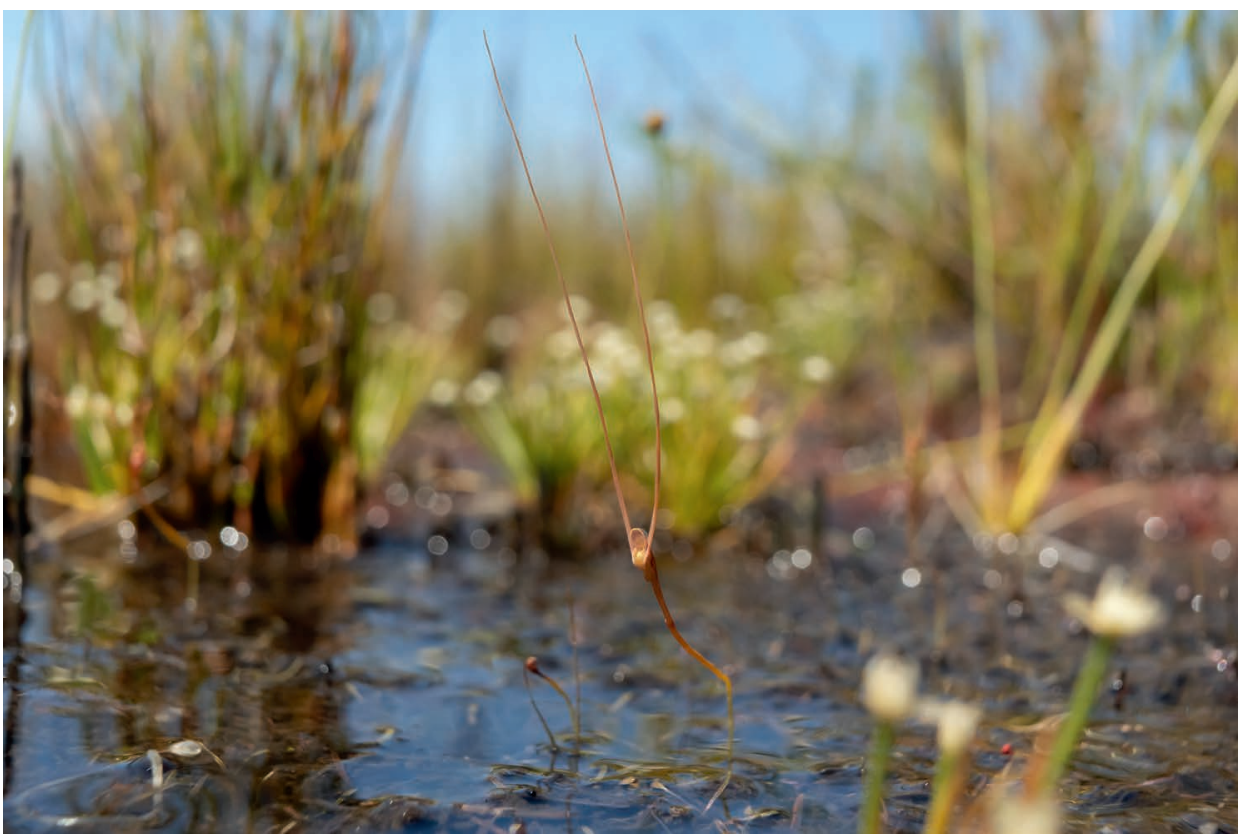

Figure 7: Utricularia dunstaniae. 
area had receded such that only a percolating pool of water a centimeter deep remained, and it was in this finely balanced microhabitat that I found the elusive species.

Behind the drops of sweat, a slight grin crept across my face as I realized my gamble in timing had paid off. Incredible luck is needed when botanizing in the Top End, and you just have to find yourself in the right place at the right time. Had I visited this site on the first day of the expedition, it would have been too flooded to induce flowering, and in another week this puddle will disappear into thin air. Likewise, the Utricularia of the sand plains will soon perish, persisting only as seed that awaits the monsoon rains in an endless cycle of wet and dry.

Acknowledgements: The author thanks Peter Eggenhuizen and Wey Yao Wong for their companionship throughout the trip; Richard Nunn, Andrew Broome, and Thilo Krueger for their insight and discussions of the field; and the broader carnivorous plant community, whose support motivates me to find these amazing plants.

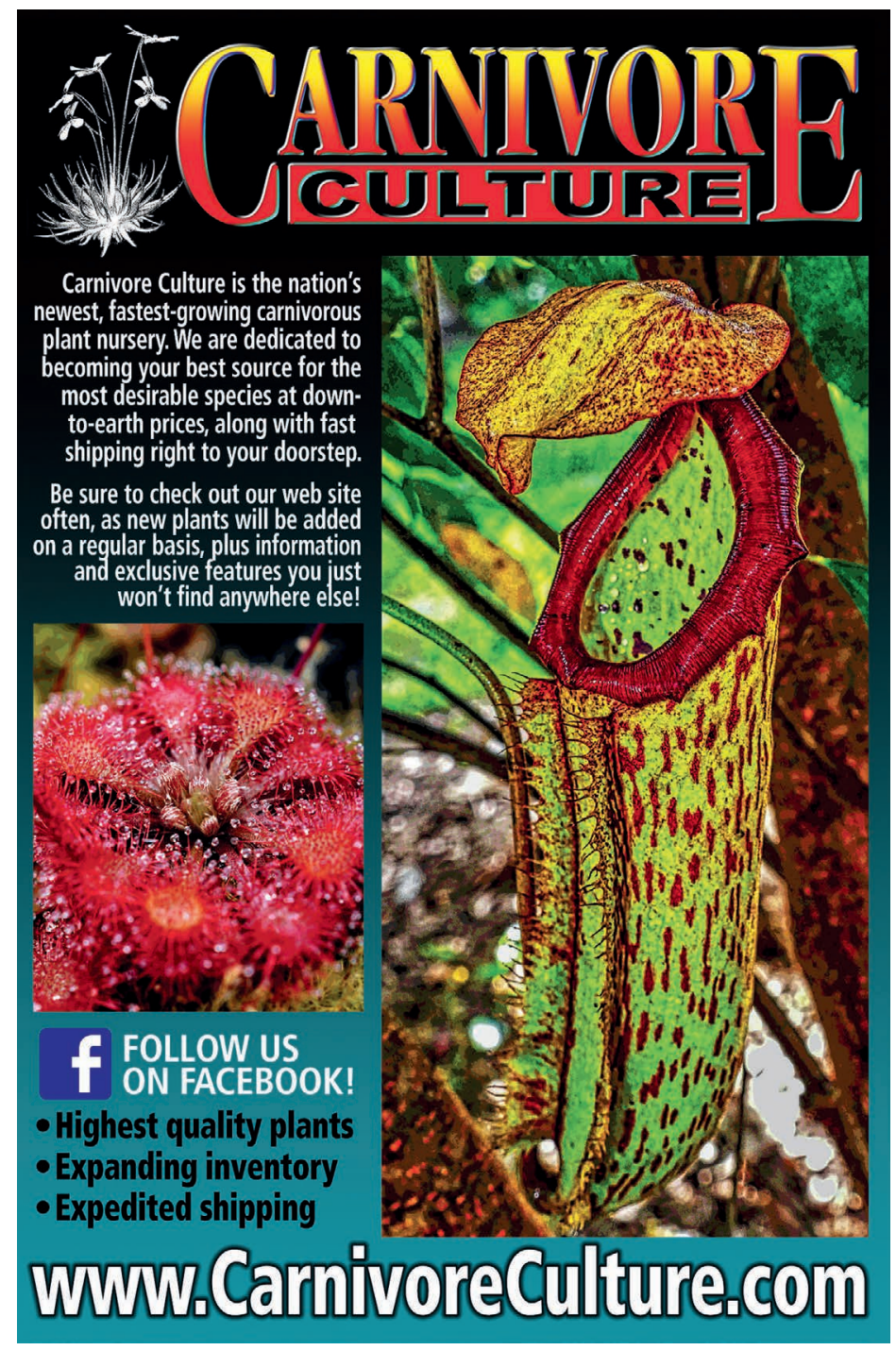




\section{CARNIVOROUS PLANT NEWSLETTER}

Journal of the International Carnivorous Plant Society

Volume 50, No. 3

September 2021

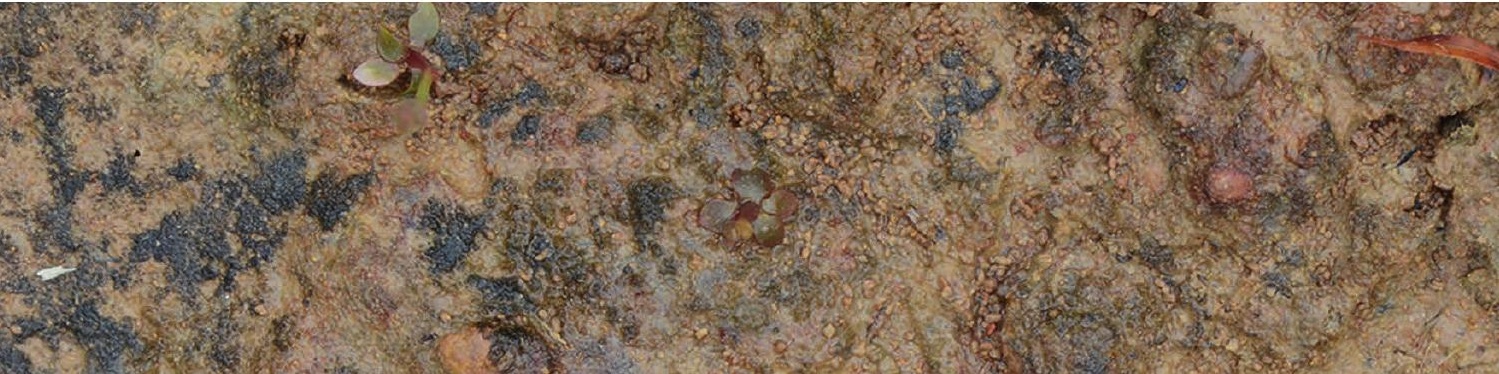

6hing:

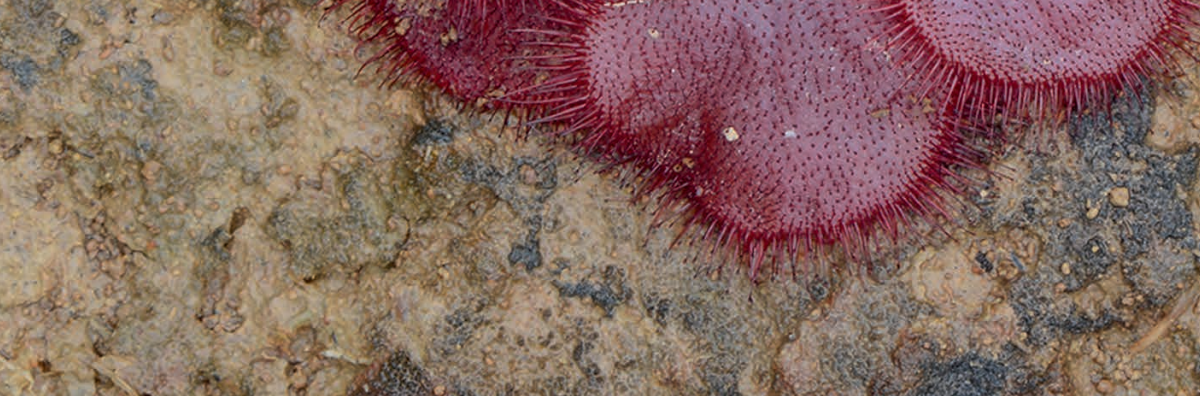

4

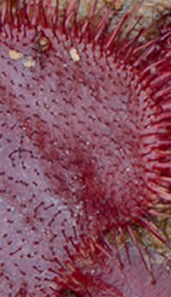




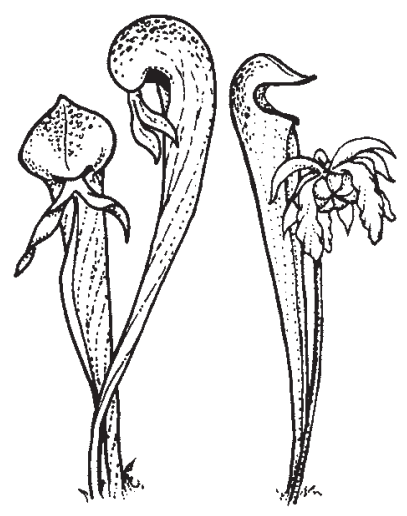

\section{CARNIVOROUS \\ PLANT \\ NEWSLETTER}

Journal of the International

Carnivorous Plant Society

www.carnivorousplants.org

\section{Volume 50, Number 3 September 2021}

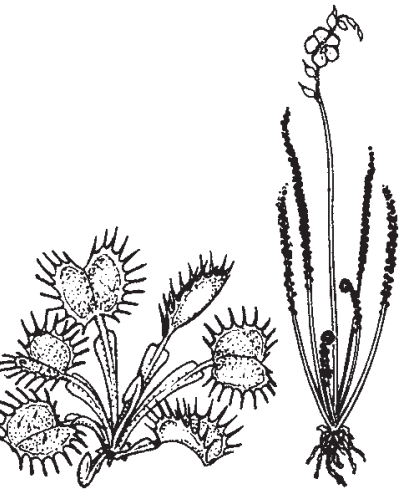

Front Cover: Drosera falconeri in full growth in the Darwin area, Northern Territory, Australia. Photo by R. Nunn. Articles on page 118 and 133.

Back Cover: Drosera fulva at the end of the wet season, growing at Noonamah, Northern Territory, Australia. Photo by R. Nunn. Article on page 118.

Carnivorous Plant Newsletter is dedicated to spreading knowledge and news related to carnivorous plants. Reader contributions are essential for this mission to be successful. Do not hesitate to contact the editors with information about your plants, conservation projects, field trips, or noteworthy events. Advertisers should contact the editors. Views expressed in this publication are those of the authors, not the editorial staff.

All correspondence regarding dues, address changes and missing issues should be sent to the Membership Coordinator at the ICPS. Do not send such correspondence to the editors. Checks for subscriptions should be made to the International Carnivorous Plant Society in US funds. Dues, including a subscription, are \$35 per year.

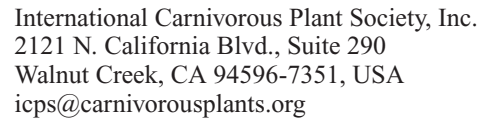

President

Vice President

Secretary

Treasurer

Board Member

Board Member

Board Member

Board Member

Board Member

Membership Coordinator

Webmaster

Media Coordinator

Seed Bank Manager

Facebook Manager
Richard Nunn, richardnunn@carnivorousplants.org

John Brittnacher, john@carnivorousplants.org

Cindy Slezak, cindy@carnivorousplants.org

Daniela Ribbecke, daniela@carnivorousplants.org

Kenny Coogan, Education Director, kenny@carnivorousplants.org

Brent Jones, brent@carnivorousplants.org

Jan Schlauer, Cultivar Registrar, jan@carnivorousplants.org

Carson Trexler, Conservation Director, carson@carnivorousplants.org

Bob Ziemer, bob@carnivorousplants.org

Cindy Slezak, cindy@carnivorousplants.org

John Brittnacher, john@carnivorousplants.org

Chad Williams, chad@carnivorousplants.org

Joe Griffin, joe@carnivorousplants.org

Marcel van den Broek, marcel@carnivorousplants.org
CPN Editors

Managing Editor

Editor

Editor

Editor editor@carnivorousplants.org
Bob Ziemer
Barry Rice
Karl Herold

John Brittnacher
Science Editor

Science Editor

Science Editor
Andreas Fleischmann

Fernando Rivadavia

Jan Schlauer

Date of effective publication of the June 2021 issue of Carnivorous Plant Newsletter: May 11, 2021.

The ICPS is the International Cultivar Registration Authority (ICRA) for the names of cultivated carnivorous plants according to the International Code of Nomenclature for Cultivated Plants. Send relevant correspondence to the ICPS, Inc.

Carnivorous Plant Newsletter is published quarterly in March, June, September, and December by the ICPS, Inc., 2121 N. California Blvd., Suite 290, Walnut Creek, CA 94596, USA. Periodicals postage paid at Walnut Creek, CA and additional mailing offices. Postmaster: Send address changes to ICPS, Inc., 2121 N. California Blvd., Suite 290, Walnut Creek, CA 94596, USA. Printed by Allen Press, Inc., 810 E. 10th Street, Lawrence, KS 66044. Logo and masthead art: Paul Milauskas. (C) 2021 International Carnivorous Plant Society. All rights reserved. ISSN \#0190-9215 